\title{
Therapeutic Effect of Stereospermum suavelolens on Diabetic Nephropathy
}

\author{
Thirumalaiswamy Balasubramanian ${ }^{1^{*}}$, Senthilkumar GP $^{2}$, Karthikeyan $\mathbf{M}^{1}$ and Tapan Kumar Chatterjee ${ }^{3}$ \\ ${ }^{1}$ Department of Pharmacology, Al Shifa College of Pharmacy, Poonthavanam Post, Kizhattur Village, Perinthalmanna, Malappuram District, Kerala, India \\ ${ }^{2}$ Department of Pharmaceutical Chemistry, Bharathi College of Pharmacy, Bharathi Nagara, Mandya, Karnataka, India \\ ${ }^{3}$ Division of Pharmacology, Department of Pharmaceutical Technology, Jadavpur University, Kolkata, India
}

"Corresponding author: Dr. Thirumalaiswamy Balasubramanian, Department of Pharmacology, Al Shifa College of Pharmacy, Poonthavanam Post, Kizhattur Village, Perinthalmanna, Malappuram Dist, Kerala 679 325, India, Tel: +919544496752; E-mail: tbaluanandhi@gmail.com

Received: August 05, 2014; Accepted: September 25, 2014; Published: September 30, 2014

Copyright: (c) 2014 Balasubramanian T, et al. This is an open-access article distributed under the terms of the Creative Commons Attribution License, which permits unrestricted use, distribution, and reproduction in any medium, provided the original author and source are credited.

\begin{abstract}
Objective: In Indian traditional medicine, decoctions from different parts of Stereospermum suavelolens are used for the treatment of various human diseases including diabetes mellitus. The present study was aimed to evaluate ethyl acetate fraction of ethanol extract from Stereospermum suavelolens for nephroprotective effects in Streptozotocin (STZ)-induced diabetic rats by sub acute model.

Methods: The STZ induced diabetic rats were treated once daily, orally with ethyl acetate fraction of Stereospermum suavelolens for 14 days at the doses of 200 and $400 \mathrm{mg} / \mathrm{kg}$. The serum and urine renal function parameters-creatinine, urea, uric acid, albumin and total proteins were measured on $15^{\text {th }}$ day. The in vivo antioxidant activity of Stereospermum suavelolens was also evaluated in diabetic rats. Effects of the fraction treatments on the kidney histological profile in STZ nephrotoxic rats were also evaluated.

Results: The present study investigation showed that the ethyl acetate fraction of Stereospermum suavelolens significantly $(P<0.001)$ attenuated elevations in the serum levels of creatinine, urea, uric acid and total proteins in diabetic treated rats as compared with diabetic control rats. Significant $(P<0.001)$ increase in Superoxide Dismutase (SOD), reduced Glutathione (GSH) and Catalase (CAT) levels and reduction in Thiobarbituric Acid Reactive Substances (TBARS) levels were also observed in ethyl acetate fraction treated rats kidney. The histopathological study of kidney in drug treated rats shows significant protective effect against STZ oxidative stress.
\end{abstract}

Conclusion: Our study concludes that the ethyl acetate fractions of Stereospermum suavelolens possess potent nephroprotective effect against oxidative stress in STZ induced diabetic rats.

Keywords: Stereospermum suavelolens, Ethyl acetate fraction; STZ induced diabetic rats; Nephroprotective effect; Creatinine; Urea; Uric acid; In vivo antioxidant activity; Histopathological study

\section{Introduction}

Diabetes Nephropathy is a complex disorder that is characterized by elevated levels of serum glucose, creatinine and uric acid in addition to abnormal histopathological changes in kidney. Not with standing much research work, the diabetic kidney damages are increasing rapidly and patients with diabetes kidney failure undergo either painful dialysis or kidney transplantation [1] which is both costly and harmful. In the absence of reliable and effective modern nephroprotective drugs and available traditional medicines employed for the disease treatment, concerted efforts are currently channeled toward exploring complementary or alternative medicine from natural sources having potent antidiabetic as well as nephroprotective activity with fewer side effects. Traditional medicines and extracts from medicinal plants have been extensively used as alternative medicine for better control and management of diabetes nephropathy [2].

Stereospermum suaveolens (Family: Bignoniaceae), popularly known as "padiri", is a large deciduous tree distributed in the moist parts of India. Different parts of this plant have various therapeutic applications in native medicine. Traditionally, a decoction of the root is used for the treatment of inflammation, pain, fever, asthma, and vomiting $[3,4]$. The flowers mixed with honey are given orally for the control of hiccups [5]. In southern India the bark is used in folk medicine for the treatment of diabetes [3]. The fruit is useful for the treatment of leprosy. The plant root extract is known to possess anticancer activity due to the presence of lapachol $[3,6]$. Previous phytochemical studies showed presence of higher carboxylic acids, $\beta$ sitosterol and saponin [3] in the roots, lapachol, dehydro- $\alpha$-lapachone [7], sterekunthal B, sterequinone $\mathrm{C}$, stere-ochenols $\mathrm{A}$ and $\mathrm{B}[8,9]$ in the bark, and stereolensin [6], scutellarein, 6-hydroxy luteolin [10], dinatin (4,5,7-trihydroxyl-6-methoxyflavon), and dinatin-7glucuroniside [11] in the leaves. Previous studies in our laboratory showed that the ethanol extract of Stereospermum suaveolens have anti diabetic activity in STZ induced diabetic rats. However, based on the literature survey, there is no scientific report proving the neproprotective effect of this particular species. Therefore, the current study was designed to evaluate the neproprotective activity of Stereospermum suaveolens in STZ induced diabetic rats. 


\section{Materials and Methods}

\section{Chemicals}

(STZ), Trichloro Acetic Acid (TCA), Thiobarbituric Acid (TBA), reduced Glutathione (GSH), TrisHCl, Sodium Dodecyl Sulfate (SDS), Nitro Blue Tetrazolium (NBT), reduced Nicotinamide Adenine Dinucleotide Phosphate (NADH), Dimetylsulfoxide (DMSO) and Phenazinemethosulfate (PMS) were purchased from SISCO Research Laboratory, Mumbai, India. Glibenclamide was obtained from Prudence PharmaChem, Ankeshwara, Gujarat, India. The solvents and chemicals used were of analytical grade.

\section{Plant material}

The plant was identified and authenticated by the Tropical Botanical Garden and Research Institute, Palode, Tiruvanthapuram district, Kerala and a voucher specimen (TBS-1) has been deposited in our laboratory for further reference. The bark of Stereospermum suavelolens (Roxb.) DC was collected during October 2010 from Palode forest, Thiruvanthapuram district, Kerala, India. The bark of the plant was dried under shade and powdered with a mechanical grinder. The powdered plant material was then passed though sieve No\# 40 and stored in an air tight container for future use.

\section{Preparation of plant ethyl acetate fraction}

The shade dried coarse powdered bark of Stereospermum suavelolens $(500 \mathrm{~g})$ was packed in the soxhlet extraction apparatus and extracted with $1.5 \mathrm{~L}$ of $95 \%$ ethanol at a temperature of $40-50^{\circ} \mathrm{C}$ for 72 h. The extract was filtered and the filtered extract was then concentrated to dryness in a rotary evaporator under reduced pressure at temperature of $40^{\circ} \mathrm{C}$. Then the crude ethanol extract of Stereospermum suavelolens was fractionated with ethyl acetate. The resultant black color ethyl acetate fraction residue was stored in desiccators for use in subsequent experiments and the yield was $16.2 \%$ w/w. Weighed amount of ethyl acetate fraction was suspended in 5\% DMSO in normal saline prior to oral administration.

\section{Qualitative phytochemical analysis}

Preliminary phytochemical screening was performed for the ethyl acetate fraction of EESS [12-14].

\begin{abstract}
Animals
Male Wistar albino rats weighing 150-200 g and male Swiss albino mice weighing 20-25 g were purchased from M/S-Ghosh Enterprises, Kolkata, India. The animals were randomly grouped $(n=6)$ and housed in polyacrylic cages $(38 \times 23 \times 10 \mathrm{~cm})$ and maintained under standard laboratory conditions $\left(25 \pm 2{ }^{\circ} \mathrm{C}\right)$ with dark and light cycle $(14 / 10 \mathrm{~h})$. They were allowed free access to standard dry pellet diet (Hindustan Lever, Kolkata, India) and water ad libitum. The rats were acclimatized to laboratory condition for 1 week before commencement of experiment. Ethical clearance was obtained from Jadavpur University Animals Ethical Committee for using animals in the present study.
\end{abstract}

\section{Acute toxicity study}

An acute oral toxicity study was performed as per Organization for Economic Co-operation and Development (OECD) 423 guidelines. Male Swiss albino mice (20-25 g) were randomly distributed in six groups of three each. The animals were fasted overnight, and the ethylacetate fraction was administered orally at a dose of up to $2000 \mathrm{mg} / \mathrm{kg}$. The animals were closely observed for the first $24 \mathrm{~h}$ for any toxic symptoms and for $72 \mathrm{~h}$ for any mortality.

\section{Experimental induction of diabetes}

Rats were fasted for $16 \mathrm{~h}$ before the induction of diabetes with STZ. A freshly prepared solution of STZ $(50 \mathrm{mg} / \mathrm{kg})$ in $0.1 \mathrm{M}$ cold citrate buffer, $\mathrm{pH}$ : 4.5, were injected intraperitoneally in a volume of $1 \mathrm{ml} / \mathrm{kg}$ [15] and the control rats were injected with citrate buffer alone. In order to control the hypoglycemia during the first day after the STZ administration, diabetic rats were given $5 \%$ glucose solution orally. Hyperglycemia was confirmed by the elevated fasting glucose levels in blood, determined at $48 \mathrm{~h}$ and then on day 6 after injection. Rats with moderate diabetes exhibiting fasting blood glucose levels in the range of $280-325 \mathrm{mg} / 100 \mathrm{ml}$ were selected for the studies.

\section{Nephroprotective activity study in diabetic rats (14 days)}

Rats were fasted for $16 \mathrm{~h}$ and divided into five groups of six each [16]. Group I, nondiabetic control, were given 5\% DMSO in normal saline orally at a dose of $5 \mathrm{ml} / \mathrm{kg}$. Group II, STZ-diabetic control, received $5 \%$ DMSO in normal saline at a dose of $5 \mathrm{ml} / \mathrm{kg}$ orally. Group III and IV, STZ-diabetic rats, were treated with ethyl acetate fraction orally at a dose of 200 and $400 \mathrm{mg} / \mathrm{kg}$, respectively. Group VII STZdiabetic rats were administered with standard drug Glibenclamide at a dose of $0.5 \mathrm{mg} / \mathrm{kg}$ orally. The treatment was continued once daily for 14 days.

\section{Effect of ethyl acetate fraction on serum and urine renal parameters}

On the $15^{\text {th }}$ day, blood was collected from the overnight-fasted rats by retro-orbital bleeding, using microcapillary technique. Fasting blood glucose level of each animal was determined. Serum was separated and used for the determination of biochemical parameters, such as creatinine, urea, uric acid and total proteins (using Automated Span Diagnostic Reagents, Mumbai, India). Rats were accommodated in metabolic cages for urine collection for 2 days in order to become familiar with the environment of the cage. Twenty-four hour urine samples were collected from all groups to determine urine total protein and albumin. After urine collection, all the rats were sacrificed by euthanasia. Kidneys were excised immediately and washed with ice cold saline solution.

\section{Estimation of antioxidant enzyme assays}

A $10 \%$ w/v of kidney homogenate was prepared in $0.15 \mathrm{M}$ Tris- $\mathrm{HCl}$ buffer ( $\mathrm{pH}$ : 7.4). The homogenate was centrifuged at $2000 \times \mathrm{g}$ for 20 $\min$ at $4^{\circ} \mathrm{C}$ to remove the cell debris and then the supernatant was centrifuged (REMI C-24) at $12,000 \times \mathrm{g}$ for $1 \mathrm{~h}$ at $4^{\circ} \mathrm{C}$. The supernatant obtained were used for the determination of lipid peroxidation [17], reduced gluthathione content [18], Superoxide Dismutase (SOD) [19] and Catalase (CAT) [20].

\section{Histopathological study}

The fragments from the kidney tissues were fixed in $10 \%$ neutral formalin solution, embedded in paraffin, and then, stained with Hematoxylin (H) and Eosin (E). The sections were examined microscopically for the evaluation of histopathological changes. 
Citation: Balasubramanian T, Senthilkumar GP, Karthikeyan M, Chatterjee TK (2014) Therapeutic Effect of Stereospermum suavelolens on

Page 3 of 7

\section{Statistical analysis}

The experimental data were expressed as mean \pm SEM. The data were analyzed using ANOVA and Dunett's test. The results were considered statistically significance if $\mathrm{P}<0.05$.

\section{Results}

\section{Phytochemical screening}

The qualitative phytochemical analysis of the ethyl acetate fraction revealed the presence of flavonoids, tannins, alkaloids, saponins, and glycosides (Table 1).

\begin{tabular}{|l|l|}
\hline Phytoconstituents & Ethyl acetate fraction \\
\hline Alkaloids & + \\
\hline Glycosides & + \\
\hline Carbohydrates & - \\
\hline Steroids & - \\
\hline Triterpenes & - \\
\hline Saponins & + \\
\hline Tannins & + \\
\hline Proteins and amino acids & - \\
\hline
\end{tabular}

\begin{tabular}{|c|c|c|c|c|c|c|c|c|}
\hline \multirow[t]{2}{*}{ Groups } & \multirow[t]{2}{*}{ Urea (mg/dl) } & \multirow[t]{2}{*}{$\begin{array}{l}\text { Uric } \\
(\mathrm{mg} / \mathrm{dl})\end{array}$} & \multirow[t]{2}{*}{$\begin{array}{l}\text { Serum } \\
(\mathrm{mg} / \mathrm{dl})\end{array}$} & \multirow[t]{2}{*}{$\begin{array}{l}\text { Serum total } \\
\text { protein }(\mathrm{g} / \mathrm{dl})\end{array}$} & \multirow[t]{2}{*}{$\begin{array}{l}\text { Urine total } \\
\text { protein }(\mathrm{mg} / \mathrm{dl})\end{array}$} & \multirow[t]{2}{*}{$\begin{array}{l}\text { Urine albumin } \\
(\mathrm{mg} / \mathrm{dl})\end{array}$} & \multicolumn{2}{|c|}{$\begin{array}{l}\text { Serum glucose levels } \\
(\mathrm{mg} / \mathrm{dl})\end{array}$} \\
\hline & & & & & & & $1^{\text {st }}$ day & $15^{\text {th }}$ day \\
\hline $\begin{array}{l}\text { Nondiabetic control } \\
\left(\begin{array}{l}5 \% \quad \text { DMSO in } 0.9 \% \\
\mathrm{NaCl}, 5 \mathrm{ml} / \mathrm{kg})\end{array}\right.\end{array}$ & $24.38 \pm 2.15$ & $2.92 \pm 0.15$ & $0.73 \pm 0.06$ & $7.14 \pm 0.23$ & $14.68 \pm 0.89$ & $2.30 \pm 0.13$ & $\begin{array}{ll}85.64 \quad \pm \\
1.99\end{array}$ & $\begin{array}{l}86.60 \\
1.91\end{array}$ \\
\hline $\begin{array}{lr}\text { STZinduced } & \text { diabetic } \\
\text { control }(5 \% \text { DMSO } & \text { in } \\
0.9 \% ~ N a C l & 5 \mathrm{ml} / \mathrm{kg}))\end{array}$ & $61.73 \pm 1.72 \mathrm{a},{ }^{* *}$ & $3.99 \pm 2.15 \mathrm{a},{ }^{* *}$ & $1.96 \pm 0.13 a,{ }^{* *}$ & $3.26 \pm 0.45 \mathrm{a},{ }^{* *}$ & $\begin{array}{l}33.91 \pm 1.68 \\
a,{ }^{* *}\end{array}$ & $14.02 \pm 0.98 \mathrm{a},{ }^{* *}$ & $\begin{array}{l}290.65 \pm \\
1.86 a,{ }^{* *}\end{array}$ & $\begin{array}{l}293.40 \\
2.42 \mathrm{a}^{, * *}\end{array}$ \\
\hline $\begin{array}{l}\text { STZ+Ethyl acetate } \\
\text { fraction }(200 \mathrm{mg} / \mathrm{kg})\end{array}$ & $36.53 \pm 1.51 \mathrm{~b},{ }^{* *}$ & $3.12 \pm 0.12 b,{ }^{* *}$ & $0.81 \pm 0.12 b,^{* *}$ & $5.94 \pm 0.45 b,{ }^{* *}$ & $\begin{array}{l}20.04 \pm 1.09 \\
b^{* *}\end{array}$ & $6.70 \pm 0.46 \mathrm{~b},{ }^{* *}$ & $\begin{array}{l}284.81 \pm \\
1.96 \mathrm{~b},{ }^{* *}\end{array}$ & $\begin{array}{l}145.42 \\
1.99 \mathrm{~b}, \text {,* }\end{array}$ \\
\hline $\begin{array}{l}\text { STZ+Ethyl acetate } \\
\text { fraction }(400 \mathrm{mg} / \mathrm{kg})\end{array}$ & $29.50 \pm 1.38 \mathrm{~b},{ }^{* *}$ & $3.09 \pm 0.12 b,{ }^{* *}$ & $0.72 \pm 0.05 b,{ }^{* *}$ & $6.52 \pm 0.35 b,{ }^{* *}$ & $\begin{array}{l}17.40 \pm 0.57 \\
b^{* *}\end{array}$ & $4.51 \pm 0.33 b,{ }^{* *}$ & $\begin{array}{l}283.28 \pm \\
1.16 \mathrm{~b},{ }^{\star *}\end{array}$ & $\begin{array}{l}124.12 \pm \\
1.13 b,{ }^{* *}\end{array}$ \\
\hline $\begin{array}{l}\text { STZ+Glibenclamide }(0.5 \\
\mathrm{mg} / \mathrm{kg})\end{array}$ & $30.25 \pm 1.27 \mathrm{~b},{ }^{* *}$ & $3.04 \pm 0.12 b,{ }^{* *}$ & $0.80 \pm 0.24 \mathrm{~b},{ }^{* *}$ & $6.61 \pm 0.36 \mathrm{~b},{ }^{* *}$ & $18.24 \pm 0.79 \mathrm{~b},{ }^{* *}$ & $6.40 \pm 0.22 b,{ }^{* *}$ & $\begin{array}{l}286.50 \pm \\
6.35 \mathrm{~b}^{\text {,* }}\end{array}$ & ${ }_{, * *}^{115 \pm 6.11 b}$ \\
\hline
\end{tabular}

Table 2: Effect of ethyl acetate fractions of Stereospermum suaveolens on serum and urine renal biomarkers. Values are mean \pm SEM; six rats in each group; $a{ }^{* \star} \mathrm{P}<0.001$ as compared to nondiabetic control group; $b,{ }^{*} \mathrm{P}<0.001$ when compared with STZtreated control group; DMSO: Dimethylsulfoxide; STZ: Streptozotocin

\section{Effects on renal in vivo antioxidant activities}

\section{Lipid peroxidation}

STZ-induced diabetic rats show an increased TBARS (Thiobarbituric Acid Reactive Substances) level in kidney (Table 3) as compared to nondiabetic rats. However, treatment with ethyl acetate

\begin{tabular}{|l|l}
\hline Flavanoids & + \\
\hline
\end{tabular}

Table 1: Phytochemical constituents of Stereospermum suaveolens bark. Note: + and - symbol represent presence and absence of phytoconstituent respectively

\section{Acute toxicity study}

No mortality and no toxic manifestations were observed up to a dose of $2000 \mathrm{mg} / \mathrm{kg}$. Further dosing was not performed to estimate the LD50 (Lethal Dose) value. According to the OECD guidelines for acute toxicity, an LD50 dose of $2000 \mathrm{mg} / \mathrm{kg}$ and above is categorized as unclassified; hence, the drug is found to be safe. Based on the acute toxicity studies, doses of 200 and $400 \mathrm{mg} / \mathrm{kg}$ for the ethyl-acetate fraction have been selected as therapeutic doses.

\section{Effect on serum and urine renal function parameters}

Oral administration of a dose of 200 and $400 \mathrm{mg} / \mathrm{kg}$ of the ethyl acetate fraction of EESS to STZ-induced diabetic rats significantly $(\mathrm{P}<0.001)$ reduced the elevated fasting blood glucose levels, when compared to diabetic control rats. The changes in the level of serum urea, uric acid, creatinine and total protein, and urine total protein and albumin in non-diabetic control, STZ-induced diabetic control and fractions treated rats were illustrated in Table 2. Compared to the non-diabetic control rats, urea, creatinine and total proteins levels increased significantly $(\mathrm{P}<0.001)$, in STZ-induced diabetic control rats. Treatment of STZ-induced diabetic rats with ethyl acetate fractions of EESS for 14 days resulted in marked decrease in serum urea, creatinine $(\mathrm{P}<0.001$, respectively) as compared to diabetic control rats. 
Citation: Balasubramanian T, Senthilkumar GP, Karthikeyan M, Chatterjee TK (2014) Therapeutic Effect of Stereospermum suavelolens on Diabetic Nephropathy. Clin Exp Pharmacol 4: 162. doi:10.4172/2161-1459.1000162

Page 4 of 7

significantly $(\mathrm{P}<0.001)$ increased total GSH in kidney when compared to STZ-induced diabetic control rats and is shown in Table 3.

\section{Superoxide dismutase and catalase}

SOD and Catalase (CAT) activities in the STZ-induced diabetic rats were significantly $(\mathrm{P}<0.001)$ decreased in kidney. Administration of ethyl acetate fractions significantly $(\mathrm{P}<0.001)$ increased the SOD and CAT activities compared to STZ-induced diabetic rats and is shown in Table 3.

\begin{tabular}{|c|c|c|c|c|}
\hline Groups & $\begin{array}{l}\text { Lipid peroxidation } \\
\text { (nmol of MDA/mg protein) }\end{array}$ & $\begin{array}{l}\text { Glutathione } \\
\text { ( } \mu \mathrm{M} / \mathrm{gm} \text { protein) }\end{array}$ & $\begin{array}{l}\text { Superoxide dismutase } \\
\text { (IU/mg protein) }\end{array}$ & $\begin{array}{l}\text { Catalase } \\
\text { (nmol of } \mathrm{H} 2 \mathrm{O} 2 \text { decomposed } / \mathrm{min} / \mathrm{mg} \\
\text { protein) }\end{array}$ \\
\hline $\begin{array}{l}\text { Nondiabetic control } \\
(5 \% \text { DMSO in } 0.9 \% \mathrm{NaCl}, 5 \mathrm{ml} / \mathrm{kg})\end{array}$ & $9.36 \pm 0.72$ & $31.79 \pm 0.77$ & $20.63 \pm 1.21$ & $53.45 \pm 1.20$ \\
\hline $\begin{array}{l}\text { STZinduced diabetic control } \\
(5 \% \mathrm{DMSO} \text { in } 0.9 \% \mathrm{NaCl}, 5 \mathrm{ml} / \mathrm{kg})\end{array}$ & $23.92 \pm 1.81 \mathrm{a},{ }^{* *}$ & $17.26 \pm 0.37 \mathrm{a},{ }^{* *}$ & $8.95 \pm 0.18 a,{ }^{* *}$ & $22.31 \pm 1.19 \mathrm{a},{ }^{* *}$ \\
\hline $\begin{array}{l}\text { STZ+Ethyl acetate fraction } \\
(200 \mathrm{mg} / \mathrm{kg})\end{array}$ & $18.92 \pm 0.52 b,{ }^{* *}$ & $24.07 \pm 1.22 \mathrm{~b},{ }^{* *}$ & $14.25 \pm 0.12 b,{ }^{* *}$ & $35.50 \pm 1.26 \mathrm{~b},{ }^{* *}$ \\
\hline $\begin{array}{l}\text { STZ+Ethyl acetate fraction } \\
(400 \mathrm{mg} / \mathrm{kg})\end{array}$ & $13.28 \pm 0.65 \mathrm{~b},{ }^{* *}$ & $28.83 \pm 0.49 \mathrm{~b},{ }^{* *}$ & $17.23 \pm 0.33 b,{ }^{* *}$ & $41.94 \pm 1.10 \mathrm{~b},{ }^{* *}$ \\
\hline $\begin{array}{l}\text { STZ+Glibenclamide } \\
(0.5 \mathrm{mg} / \mathrm{kg})\end{array}$ & $19.33 \pm 0.92 b,{ }^{* *}$ & $22.73 \pm 0.41 \mathrm{~b},{ }^{* *}$ & $15.42 \pm 0.34 \mathrm{~b},{ }^{* *}$ & $34.08 \pm 0.97 \mathrm{~b},{ }^{* *}$ \\
\hline
\end{tabular}

Table 3: Effect of ethyl acetate fractions of Stereospermum suaveolens on kidney antioxidants. Values are mean \pm SEM; six rats in each group; $\mathrm{a},{ }^{* *} \mathrm{P}<0.001$ as compared to nondiabetic control group; $\mathrm{b},{ }^{* *} \mathrm{P}<0.001$ when compared with STZtreated control group; DMSO: Dimethylsulfoxide; STZ: Streptozotocin; MDA: Malondialdehyde

\section{Histopathalogical studies of kidney}

Figure 1 shows kidney section of nondiabetic control rats with normal Glomeruli (GL), intact Bowman's Capsule (BM), Proximal Convoluted (CT) and Distal Convoluted (DT) tubules. In STZinduced diabetic control kidney (Figure 2) resulted in glomerular hypertrophy, mild thickening of basement membrane, increased Bowman's space, tubular dilation, and interstitial inflammatory cell infiltration. Treatment with ethyl acetate fractions $(200$ and $400 \mathrm{mg} / \mathrm{kg}$ and glibenclaimde $(0.5 \mathrm{~m} / \mathrm{kg}$ (Figures $3-5)$ reduced cell infiltration, reduced tubular necrosis, show normal Bowman's space with glomerulus, basement membrane and capillaries, and maintaining near normal kidney architecture.

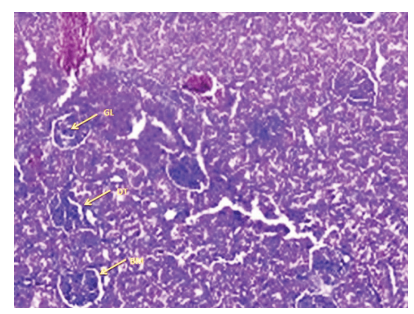

Figure 1: A sectional representation of normal rat kidney at $\mathrm{x} 400$ magnification (Haematoxylin and Eosin stain) showing normal Glomeruli (GL) with an intact Bowman's capsule (BM), Proximal convoluted (CT) and Distal convoluted (DT) tubules.

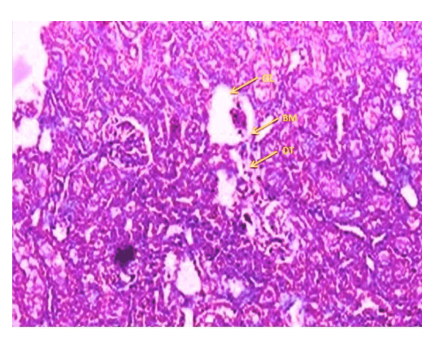

Figure 2: A representative section of STZ diabetic control rat kidney at x400 magnification (Haematoxylin and Eosin) showing severe glomerular degeneration, mild change density of mesenchyme, thickening of the basement membrane, proximal convoluted tubular degeneration, obliterated distal convoluted tubular lumen increased Bowman's space, interstitial inflammatory cell infiltration and tubular dilation. 


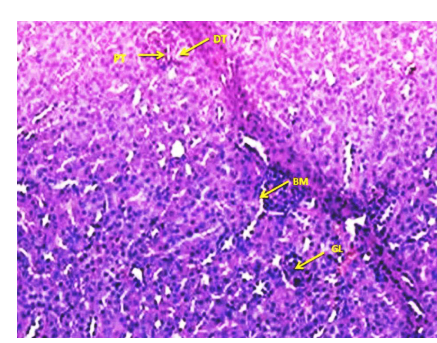

Figure 3: A representative section of $200 \mathrm{mg} / \mathrm{kg} /$ day ethyl acetate fraction treated, STZ diabetic rat kidney at $\mathrm{x} 400$ magnification (Haematoxylin and Eosin) showing moderate tubular degeneration with mild glomerular degeneration and mild increased Bowman's space.

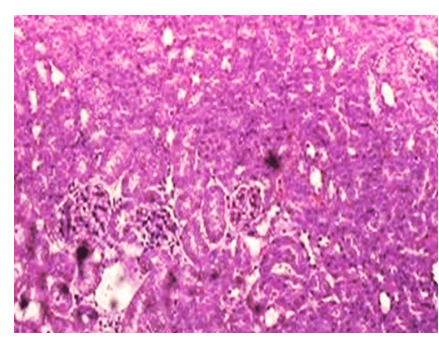

Figure 4: A sectional representation of $400 \mathrm{mg} / \mathrm{kg} /$ day ethyl acetate fraction treated, STZ diabetic rat kidney at $\mathrm{x} 400$ magnification (Haematoxylin and Eosin) showing normal glomeruli encapsulated in normal Bowman's capsule. There is mild tubular degeneration interposed with normal proximal convoluted tubule and distal convoluted tubule.

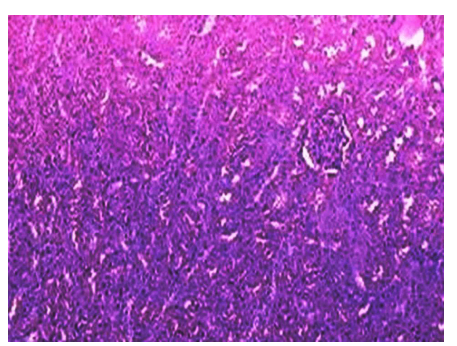

Figure 5: A sectional representation of $0.5 \mathrm{mg} / \mathrm{kg} /$ day Glibenclamide treated, STZ diabetic rat kidney at $\mathrm{x} 400$ magnification (Haematoxylin and Eosin) showing normal glomeruli encapsulated by normal Bowman's capsule.

\section{Discussion}

In people with diabetes mellitus, the diabetic nephropathy is the most important cause of death, of whom, $30-40 \%$ eventually develop end-stage renal failure [21]. A number of clinical studies suggest that the antioxidants in plants are key factors in reducing the incidence of diabetic nephropathy [22,23]. Finding new natural sources of antioxidants with potential antidiabetic activity can be useful to future therapy against diabetic mellitus and its complications.
The present study was conducted to evaluate the nephroprotective effect of ethyl acetate fraction of Stereospermum suavelolens in STZ Diabetes mellitus rats. Experimental diabetes mellitus was induced in rats by injecting STZ, which is probably due to the destruction of $\beta$ cells of pancreas [24]. Several studies reported that STZ administration elevated serum renal markers in rats $[25,26]$ which is the indicator of diabetic nephropathy with altered glomerular filtration rate. The current study also revealed that serum renal markers such as creatinine, urea, uric acid and total proteins levels were increased and urine total proteins and albumin levels were decreased in diabetic control rats. The daily administration of ethyl acetate fraction of Stereospermum suavelolens for 14 days caused a significant reduction in serum creatinine, serum urea, urine total protein and urine albumin levels, and a significant elevation in serum total protein levels in diabetic rats when compared to diabetic control. This data indicates that the ethyl acetate fraction improved the renal functions and reversed the damage in the kidney tissues of diabetic rats.

Moreover, it has been reported that in STZ-induced diabetic rats, the renal undergo pathological changes [27,28] and the important pathologic features of diabetic nephropathy are glomerular hypertrophy, tubular dilation, interstitial inflammatory cell infiltration, mild thickening of basement membrane along with mild changes in the density of mesenchyme with increased Bowman's space, and tubulointerstitial fibrosis [29]. These diabetic nephropathic changes were also observed in our study, in the STZ diabetic control rats. Treatment with ethyl acetate fractions (200 and $400 \mathrm{mg} / \mathrm{kg}$ and glibenclaimde $(0.5 \mathrm{~m} / \mathrm{kg}$ (Figures $3-5)$ reduced cell infiltration, improved tubular necrosis, show normal Bowman's space with glomerulus, basement membrane and capillaries, and maintaining near normal kidney architecture. In diabetes mellitus, hyperglycemia increases the generation of free radicals by glucose auto-oxidation and the increment of free radicals may lead to kidney cells damage [30]. Ethyl acetate fraction treated rats proved that the kidney cells damage might be protected by their potent antioxidant property.

In diabetic nephropathy, oxidative stress has been found to be mainly due to an increased production of reactive oxygen species and a sharp reduction of antioxidant defenses [31].

Lipid peroxidation appears to be a key element in the production of nephropathy in diabetes [32,33]. One of the most often used biomarker to investigate the oxidative damage on kidney is TBARS (MDA) a major lipid peroxidation product. It can react with the free amino group of proteins, phospholipids, and nucleic acids leading to structural modification [34]. In the present study, the oral administration of ethyl acetate fraction to the STZ diabetic rats significantly $(\mathrm{P}<0.001)$ reverted back Malonyldialdhyde $(\mathrm{MDA})$ levels to near normal values which suggests that ethyl acetate fraction of EESS might protect the kidney tissue from lipid peroxidation.

Furthermore, enhanced oxidative stress due to diabetes may also result from a dysfunction in the defense system against free radicals, such as reduction in glutathione or inactivation of SOD and CAT [35].

Glutathione, a major intracellular non protein sulphydral compound, has an important role in the generation of cellular redox state and, consequently, the imbalance in reduced GSH to oxidized glutathione ratio is a putative indicator of cellular oxidative stress $[35,36]$. The GSH levels were significantly $(\mathrm{P}<0.001)$ decreased in the kidney of diabetic control rats. Treatment with ethyl acetate fraction improved the reduced GSH level as compared to that in STZ diabetic control rats, suggesting strengthening of antioxidant defenses in 
kidney. Hence, the elevated level of GSH protects cellular proteins against oxidation through glutathione redox cycle and also directly detoxifies reactive oxygen species generated from exposure to STZ [37].

SOD and CAT are antioxidant enzymes that destroy the peroxides and play a significant role in providing antioxidant defenses to an organism. SOD acts to dismutate superoxide radicals to hydrogen peroxides which is then acted upon by GPx and CAT is a hemeprotein which catalyses the reduction of hydrogen peroxides and protects the tissues from highly reactive hydroxyl radicals [38]. Therefore, reduction in the activity of these enzymes (SOD, CAT) may result in a number of deleterious effects due to the accumulation of superoxide anion radicals and hydrogen peroxide [39].

In the present study the activities of SOD and CAT in kidney tissue extracts of the STZ-diabetic rats were significantly lower than their control ones. Some of the authors also reported decreased levels of these antioxidant enzymes (SOD, CAT) in kidney of diabetic rats [40,41]. These antioxidant enzymes SOD and CAT levels significantly increased after the treatment of ethyl acetate fraction of Ethanol Extract of Stereospermum suaveolens (EESS) in STZ-induced diabetic rats indicating the free radical scavenging activity and their protective effect against diabetic kidney cellular damage.

The above in vivo antioxidant status reveals support to neproprotective effect of ethyl acetate fraction in diabetic rats, which also supports to histopathological studies. The oral treatments with ethyl acetate fraction ameliorated renal histological lesions in diabetic rats.

Moreover, the preliminary phytochemical investigation of the ethyl acetate fraction of Stereospermum suaveolens revealed the presence of natural antioxidants as flavonoids, tannins, terpenoids and saponins. These phytochemicals have been reported to exhibit a major role in reducing oxidative stress associated with diabetes, which in turn helps in the regulation of normal kidney functions [42]. Antioxidants may have a role in the prevention of nephrotoxicity in diabetes [43]. Thus, the significant antioxidant activity of ethyl acetate fraction of against STZ induced kidney damage in diabetic rats may be attributed to the presence of screened natural antioxidants in the plant Stereospermum suaveolens.

\section{Conclusion}

The present investigation clearly indicates that ethyl acetate fraction of ethanol extract of Stereospermum suaveolens exhibits nephroprotective effect in addition to antioxidant effects in STZinduced diabetic rats. Further study on ethyl acetate fraction of Stereospermum suaveolens should be extended for the isolation and structure determination of the beneficial effect on renal function principle(s).

\section{Acknowledgments}

The authors would like to express thanks to the Principal, Al Shifa College of Pharmacy, Perinthalmanna, Kerala, for providing necessary facilities.

\section{References}

1. NIDDK: National Institute of Diabetes and Digestive and Kidney Diseases (2007) Kidney.
2. Gayathri M, Kannabiran K (2008) Antidiabetic and ameliorative potential of Ficus bengalensis bark extract in streptozotocin induced diabetic rats. Indian J Clin Biochem 23: 394-400.

3. Anonymous (1976) The Wealth of India. Raw Materials. CSIR, New Delhi, 49-52.

4. Kirtikar KR, Basu BD (1988) Indian Medicinal Plants. International Book Distributors, Dehradun, India, 1848-1849.

5. Chopra RN, Nayar SL, Chopra IC (1999) Glossary of Indian medicinal plants, 5th Ed., National Institute of Science Communication, CSIR New Delhi, 234.

6. Ramachandran AG, Mohandoss S (1988) 6-O-?-D-GlucosylscutellareinA rare flavone glycoside from tereospermumsuaveolens. J Indian Chem 65: 150-189.

7. Joshi KC, Bansal RK, Patni R (1977) Chemical examination of the roots of Stereospermum suaveolens DC. J Indian ChemSoc 54: 648-649.

8. Haque MR, Rahman KM, Begum B, Hasan CM, Rashid MA (2005) Secondary metabolites from Stereospermum chelonoides. Univ Dhaka J Pharm Sci 4: 61-64.

9. Haque MR, Rahman KM, Iskander MN, Hasan CM, Rashid MA (2006) Stereochenols A and B, two quinones from Stereospermum chelonoides. Phytochemistry 67: 2663-2665.

10. Sankara Subramanian S, Nagarajan S, Sulochana N (1972) Flavonoids of the leaves of Stereospermum suaveolens. Curr Sci 41: 102-103.

11. Ghani A (1988) Medicinal plants of Bangladesh. Chemical constituents and uses, 1st ed. Asiatic Society of Bangladesh, Dhaka, 390.

12. Horbone JB (1988) Phytochemical methods. London: Chapman and Hall, 60-66.

13. Kokate CK, Purohit AP, Gokhale SB (1998) Pharmacognosy. Pune: NiraliPrakashan, 122-128.

14. Trease GE, Evans WC (2002) Pharmacognosy. East Bourne: ELBS Publication, 93-194, 336-337.

15. Siddiqui O, Sun Y, Liu JC, Chien YW (1987) Facilitated transdermal transport of insulin. J Pharm Sci 76: 341-345.

16. Nagappa AN, Thakurdesai PA, Venkat Rao N, Singh J (2003) Antidiabetic activity of Terminalia catappa Linn fruits. J Ethnopharmacol 88: 45-50.

17. Ohkawa H, Ohishi N, Yagi K (1979) Assay for lipid peroxides in animal tissues by thiobarbituric acid reaction. Anal Biochem 95: 351-358.

18. Ellman G (1959) Tissue sulphydryl groups. Arch Biochem Biophys 82: 70-77.

19. Kakkar P, Das B, Viswanathan PN (1984) A modified spectrophotometric assay of superoxide dismutase. Indian J Biochem Biophys 21: 130-132.

20. Aebi H (1974) Catalase. In: Bergmeyer HU, ed. Methods in enzymatic analysis. Vol. 2. New York: Academic Press, 674-684.

21. Giorgino F, Laviola L, Cavallo Perin P, Solnica B, Fuller J, et al. (2004) Factors associated with progression to macroalbuminuria in microalbuminuric Type 1 diabetic patients: the EURODIAB Prospective Complications Study. Diabetologia 47: 1020-1028.

22. Gerber M, Boutron-Ruault MC, Hercberg S, Riboli E, Scalbert A, et al. (2002) [Food and cancer: state of the art about the protective effect of fruits and vegetables]. Bull Cancer 89: 293-312.

23. Kris-Etherton PM, Hecker KD, Bonanome A, Coval SM, Binkoski AE, et al. (2002) Bioactive compounds in foods: their role in the prevention of cardiovascular disease and cancer. Am J Med 113 Suppl 9B: 71S-88S.

24. Palmer AM, Thomas CR, Gopaul N, Dhir S, Anggard EE, et al. (1998) Dietary antioxidant supplementation reduces lipid peroxidation, but impairs vascular function in small mesentric arteries of the streptozotocin diabetic rats. Diabetologia 41: 148-156.

25. Alderson NL, Chachich ME, Frizzell N, Canning P, Metz TO, et al. (2004) Effect of antioxidants and ACE inhibition on chemical modification of proteins and progression of nephropathy in the streptozotocin diabetic rat. Diabetologia 47: 1385-1395.

26. Mauer SM, Steffes MW, Brown DM (1981) The kidney in diabetes. Am J Med 70: 603-612. 
Citation: Balasubramanian T, Senthilkumar GP, Karthikeyan M, Chatterjee TK (2014) Therapeutic Effect of Stereospermum suavelolens on Diabetic Nephropathy. Clin Exp Pharmacol 4: 162. doi:10.4172/2161-1459.1000162

Page 7 of 7

27. Sun JE, Ao ZH, Lu ZM, Xu HY, Zhang XM, et al. (2008) Antihyperglycemic and antilipidperoxidative effects of dry matter of culture broth of Inonotus obliquus in submerged culture on normal and alloxan-diabetes mice. J Ethnopharmacol 118: 7-13.

28. Stambe C, Atkins RC, Tesch GH, Kapoun AM, Hill PA, et al. (2003) Blockade of p38alpha MAPK ameliorates acute inflammatory renal injury in rat anti-GBM glomerulonephritis. J Am Soc Nephrol 14: 338-351.

29. Haneda M (2006) [Mechanisms for the development and progression of diabetic nephropathy]. Nihon Rinsho 64 Suppl 2: 427-432.

30. Sharma S, Kulkarni SK, Chopra K (2006) Curcumin, the active principle of turmeric (Curcuma longa), ameliorates diabetic nephropathy in rats. Clin Exp Pharmacol Physiol 33: 940-945.

31. Orhan N, Aslan M, Orhan DD, Ergun F, YeÅŸilada E (2006) In-vivo assessment of antidiabetic and antioxidant activities of grapevine leaves (Vitis vinifera) in diabetic rats. J Ethnopharmacol 108: 280-286.

32. Aydin A, Orhan H, Sayal A, Ozata M, Sahin G, et al. (2001) Oxidative stress and nitric oxide related parameters in type II diabetes mellitus: effects of glycemic control. Clin Biochem 34: 65-70.

33. Kedziora-Kornatowska K, Szram S, Kornatowski T, Szadujkis-Szadurski L, Kedziora J, et al. (2002) The effect of verapamil on the antioxidant defence system in diabetic kidney. Clin Chim Acta 322: 105-112.

34. Pandey KB, Rizvi SI (2010) Antioxidative action of resveratrol: implications for human health. Arab. J.Chem 6: 1-6.

35. Rotruck JT, Pope AL, Ganther HE, Swanson AB, Hafeman DG, et al. (1973) Selenium: biochemical role as a component of glutathione peroxidase. Science 179: 588-590.
36. Melov S (2002) Animal models of oxidative stress, aging, and therapeutic antioxidant interventions. Int J Biochem Cell Biol 34: 1395-1400.

37. Yu BP (1994) Cellular defenses against damage from reactive oxygen species. Physiol Rev 74: 139-162.

38. Bolzán AD, Bianchi MS (2002) Genotoxicity of streptozotocin. Mutat Res 512: 121-134.

39. Aragno M, Brignardello E, Tamagno E, Gatto V, Danni O, et al. (1997) Dehydroepiandrosterone administration prevents the oxidative damage induced by acute hyperglycemia in rats. J Endocrinol 155: 233-240.

40. Stanely Mainzen Prince P, Menon VP (2001) Antioxidant action of Tinospora cordifolia root extract in alloxan diabetic rats. Phytother Res 15: 213-218.

41. Muruganandan S, Gupta S, Kataria M, Lal J, Gupta PK (2002) Mangiferin protects the streptozotocin-induced oxidative damage to cardiac and renal tissues in rats. Toxicology 176: 165-173.

42. Patel DK, Kumar R, Prasad SK, Sairam K, Hemalatha S (2011) Antidiabetic and in vitro antioxidant potential of Hybanthus enneaspermus (Linn) F. Muell in streptozotocin-induced diabetic rats. Asian Pac J Trop Biomed 1: 316-322.

43. Selvan VT, Manikandan L, Senthil Kumar GP, Suresh R, Kakoti BB, et al. (2008) Antidiabetic and Antioxidant Effect of Methanol Extract of Artanema sesamoidesin Streptatozocin-Induced Diabetic Rats. Int J Appl Res Natural Products 1: 25-33. 